\title{
THE EFFECT OF NEONATAL ADMINISTRATION OF SOME DRUGS ON THE ESTROGEN RECEPTORS IN THE PROSTATE OF ADULT ALBINO RAT: A HISTOLOGICAL AND IMMUNOHISTOCHEMICAL STUDY
}

\author{
Mohamed Deiaa M. EI-Shafei* and Mohamed E.A. Mostafa ** \\ * Histology Department, Faculty of Medicine, Cairo University \\ ** Anatomy Department, Faculty of Medicine, Cairo University
}

\section{INTRODUCTION}

Normal development and function of male reproductive organs are primarily controlled by androgens (Niu et al., 2003). However, estrogen plays also a role in normal development although it is not well defined but this refers to that estrogen receptors (ER) are also present throughout the male reproductive tract. Some studies have documented the effects of exogenous estrogen on reproductive organs of both developing (McLachlan, 1981) and mature (Juniewicz, et al., 1989) males. Administration of estrogen to developing fetuses or neonates produces pronounced short - and long - term effects on the growth, histology, and functional activity of reproductive organs (William et al., 1999).

The complex control and integration of the reproductive system, which relies on multilevel hormonal control as well as autonomic nervous input, makes investigations difficult. Altered function of one component will almost have diverse secondary effects on other components. It is often difficult to separate primary and secondary events when considering mechanism of action or toxicity. Many hormones and toxicants result in wide spectrum of morphological and physiological secondary effects (Micheal et al., 1986). Moreover, our knowledge of how chemicals affect male genital organs is superficial. It is generally based on examination of the end stage result or a clinical observation of disease. In order to understand the sequelae resulting from disruption of a particular target site by hormonal manipulations, the normal physiological interaction and responses must be appreciated (Micheal et al., 1986).

However, it is clear that the male reproductive tract is more sensitive to the deleterious effects of estrogens during early development than subsequently (Pylkanen et al., 1991). An important step in understanding the role of estrogen during normal development and the deleterious effects of exogenous estrogen administration is to determine the tissue specific pattern of ER expression in these organs (Tsurusaki et al., 2003). 
It has been revealed that the developing prostate in rat and human shows broad similarity of the two species. One of the differences between the human prostate and rat prostate is the relatively low proportion of basal cells in the rat prostate, as compared to the human gland, where basal cells form a virtually continuous sheath subjacent to the luminal epithelium (Hayward et al., 1996). At birth the rat ventral prostate consists of four main epithelial cords each with four to six branching points. They showed canalization by the age of 2 days. By the $9^{\text {th }}$ day ventral prostate could contain both small solid epithelial cords and small acini with central lumina (Higgins et al., 1989).

The mature prostatic acini in the rat are lined by simple columnar epithelium with basal nuclei, a large amount of rough endoplasmic reticulum, a large Golgi apparatus, and numerous secretory droplets. The underlying basement membrane rests on a layer of connective tissue rich in fibers and smooth muscles (Creasy and Foster, 1991).

Moverare et al. (2003) reported that androgen can be aromatized into estrogen, and that estrogen is bound to a specific, high affinity estrogen receptor protein in the cytosol. The hormone-receptor complex then undergoes some undefined change in the cytoplasm before it is translocated to the nucleus. Inside the nucleus, steroid receptor complexes are found to interact with acceptor sites on the chromosomes prior to affecting a biologic response. Also, Chaisiri et al., (1978) pointed out that the normal prostate of some species contains a separate high affinity receptor protein for $17 \mathrm{~B}$ estradiol. They reported that estrogens are believed to act by a mechanism similar to that of androgens. Moreover, Bryan et al. (1983) reported that the detection of estrogen receptor in prostatic tissue would suggest the role of estrogen in growth and differentiation of this tissue.

Furthermore, Fixmer et al. (2003) stated that the presence of specific hormone receptors on or within a cell might indicate potential dependence of the cell on this specific hormone. Therefore, study of hormonal effects could possibly arrest the development of diseases in hormonal dependent organs, as prostate. However a little was known about the changes in estrogen receptors with the advancement of age.

A variety of techniques including biochemistry, autoradiography histofluorescence and recently, the most accurate. Immunohistochemistry were used to identify receptors in different cell types (Cote and Taylor, 1996).

The aim of the present work is to illustrate the histological picture of the developing rate prostate and to localize estrogen receptors (ER) distribution in attempt to understand the role of estrogen in the development of this important male accessory gland. It was also aimed to study the effect of estrogen, tamoxifen and testosterone given neonatally, on the histological picture and ER pattern of the adult prostate. 


\section{MATERIAL AND METHODS}

This study was carried out on eighty male albino rats obtained from the Nutritional Institute in Cairo. They were divided into two main groups; untreated and treated groups.

I. Untreated group: consisted of fifty rats, which were subdivided into five equal subgroups (each of ten rats), after Higgins et al. (1989).

Subgroup 1: at the age of two days (before morphogenesis of the prostate), Subgroup 2: at the age of one week (after early morphogenesis).

Subgroup 3: at the age of two weeks (early pubertal stage).

Subgroup 4: at the age of four weeks (late pubertal stage).

Subgroup 5: at the age of six weeks (maturation stage). This subgroup was considered as a control group.

II. Treated group: included thirty rats at the age of two days. They were subdivided into three subgroups.

Subgroup 1: ten rats received estrogen. Estrogen powder was suspended in distilled water. Each animal received a daily oral dose of $110 \mu \mathrm{g} / \mathrm{kg}$ which is equivalent to the daily therapeutic dose in the adult human (1.25 $\mathrm{mg}$ ).

Subgroup 2: ten rats received tamoxifen (anti-estrogen). Tamoxifen (Tamofen) tablets; each tablet contained $40 \mathrm{mg}$ tamoxifen as tamoxifen citrate, dissolved in distilled water. Each animal received a daily oral dose of $7.1 \mathrm{mg} / \mathrm{kg}$ which was equivalent to the daily therapeutic dose in the adult human $(80 \mathrm{mg})$.

Subgroup 3: ten rats received testosterone (Anderiol capsules). Each capsule contained $40 \mathrm{mg}$ testosterone (as testosterone undecanoate) dissolved in oleic acid. Each animal received daily oral dose of $7.1 \mathrm{mg} / \mathrm{kg}$, which is equivalent to the daily therapeutic dose in the adult human ( 80 $\mathrm{mg}$ ).

The dose of hormones and drugs was calculated according to the interspecies dosage conversion scheme of Paget and Barnes (1964). Each hormone was given orally for 5 days starting from the second day according to Mc Lachlan, (1981).

The rats of the untreated subgroups were sacrificed by decapitation at the age of 2 days, 1 week, 2 weeks, 4 weeks and 6 weeks respectively.

The rats of the treated subgroups were sacrificed at the age of six weeks. The prostates were dissected and specimens were obtained from the ventral lobes of each. Specimens were then fixed immediately in buff- 
ered formaline $10 \%$ at room temperature. After fixation, processing into paraffin sections was performed. The obtaine paraffin sections of $5 \mathrm{~mm}$ thickness were prepared and mounted on glass slides (tve slides were used for Immunohistochemistry).

\section{Paraffin sections were subjected to the following:}

Haematoxylin and Eosin stains.

Immunohistochemistry for existence, amount, and distribution of estrogen receptors, which is based on avidin - biotinylated - peroxidase complex technique which is an amplified technology for the detection of estrogen receptors (Zymed laboratories).

Quantitative immunohistohemistry using the image analyzer to measure the area of positive ER cytoplasmic immunoreactivity.

\section{Positive immunohistohemical tissue control}

A specimen from breast carcinoma, known to be positive control to estrogen receptors, was processed exactly as other samples. The specimen was provided under permission of Professor Akram Nouh, Professor of pathology, Pathology department, National Cancer Institute, Cairo University, without identity of the patient.

\section{Negative immunohistohemical tissue control}

It was prepared from a prostatic tissue specimen, but instead of using a primary antibody; non-immune serum was used.

\section{RESULTS}

\section{Histological Results}

\section{Untreated group}

Subgroup 1 (2day): the prostate showed epithelial cords, some of these cords had small central lumina (forming acini); most of the acini were lined by more than one layer of cubical cells. The fibromuscular stroma was very abundant (Fig 1).

Subgroup 2 (one week): the prostatic acini became more obvious with the presence of few epithelial cords. The prostatic acini were still lined by more than one layer of cubical cells. The fibromuscular stroma was abundant, however it was less than that of subgroup 1(Fig 2).

Subgroup 3 ( 2 weeks): the prostatic acini were more developed. Most of them were lined by one layer of cubical cells with widening of the central lumina. The fibromuscular stroma was less abundant (Fig 3 ). 
Subgroup 4 ( 4 weeks): the prostatic acini became well developed and lined by one layer of cuboidal or low columnar cells with wide clear central lumina. The fibromuscular stroma was greately reduced (Fig 4).

Subgroup 5 ( 6 weeks): the prostatic acini became lined by columnar epithelium with large central lumina (fully developed acini). There was minimal amount of fibromuscular stroma in between the acini. Basal cells were observed between columnar epithelium and basement membrane (Fig. 5).

\section{Treated group}

Subgroup 1: the diameter of the prostatic acini was reduced with ultimately increase in the fibromusular stroma. Some acini became lined by more than one layer of epithelial cells (epithelial hyperplasia), which led to more narrowing of their acinar lumina (Fig. 6)

Subgroup 2: no Histological differences were observed in the prostate of this group (Fig. 7) compared to the control group.

Subgroup 3: the histological picture of the prostate of this group showed no obvious histological changes (Fig. 8) compared to the control group.

\section{Immunohistochemical Results}

\section{Immunohistochemical controls}

The Positive control "Breast carcinoma"

Section of breast carcinoma showed a very strong positive ER immunor activity in the nuclei and cytoplasm of the malignant cells (Fig. 9)

The Negative control

In the section of the prostate of negative control, none of the cells displayed any positive ER immunoreactivity (Fig. 10).

\section{Untreated group}

Subgroup 1 ( 2 days): a positive ER immunoreactivity could be observed in cytoplasm and nucleus of the acinar cells. The stromal cells also showed positive ER- immunoreactivity (Fig.11).By the image analyzer, the mean area percent of the positive ER immunoreactivity was 34.692 (table 1), which was very highly significant $(P<0.001)$ (table 2$)$.

Subgroup 2 (one week): the prostate showed ER immunoreactivity in the acinar lining epithelium, in both nucleus and cytoplasm. The cells of the fibromuscular stroma showed ER immunoreactivity (Fig. 12). By the image analyzer, the mean area percent of the positive ER immunoreactivity was 5.286 (table 1) which was statistically significant $(p<0.05)$ (table 2$)$. 
Subgroup 3 (two weeks): the prostate showed ER immunoreactivity in the cytoplasm and nuclei of the acinar cells as well as cells of the fibromuscular stroma (Fig. 13). By the image analyzer, the mean area percent of the positive ER immunoreactivity was 2.723 (table 1) which was statistically non significant (table 2).

Subgroup 4 (four weeks): the prostate showed ER immunoreactivity in the cytoplasm of most of cells and some nuclei of the lining epithelium of acini. The stromal cells showed ER immunoreactivity (Fig. 14). By the image analyzer, the mean area percent of the strong positive ER immunoreactivity was 1.626 (table 1), which was statistically non significant (table 2).

Subgroup 5 (six weeks): examination of immunostained sections of this subgroup revealed positive ER reaction in epithelial lining of acini, as well as, some stromal cells. The reaction was mostly cytoplasmic (Fig. 15). By the image analyzer, the mean area percent of the positive ER immunoreactivity was 1.434 (table 1) which was statistically nonsignificant (table 2).

\section{Treated group}

Subgroup 1: the prostate showed a strong positive ER immunorectivity in the lining epithelium of acini, in both nucleus and cytoplasm. The cells of the fibromuscular stroma also showed a strong positive ER immunoreacivity (fig. 16). By the image analyzer, the mean area percent of the positive ER immunoreactivity was 9.005 (table 3) compared to 1.4 in the control group which was statistically very highly significant (table 4).

Table (1): Mean area\% of ER Immunoreactivity in rat prostate of the untreated group.

\begin{tabular}{|c|c|c|c|c|c|}
\hline $\begin{array}{c}\text { No of } \\
\text { specimen }\end{array}$ & $\begin{array}{c}\text { Subgroup } \\
\mathbf{1}\end{array}$ & $\begin{array}{c}\text { Subgroup } \\
\mathbf{2}\end{array}$ & $\begin{array}{c}\text { Subgroup } \\
\mathbf{3}\end{array}$ & $\begin{array}{c}\text { Subgroup } \\
\mathbf{4}\end{array}$ & $\begin{array}{c}\text { Subgroup } \\
\mathbf{5}\end{array}$ \\
\hline $\mathbf{1}$ & 30.27 & 6.24 & 4.24 & 1.06 & 1.61 \\
\hline $\mathbf{2}$ & 35.84 & 2.85 & 1.23 & 1.35 & 1.88 \\
\hline $\mathbf{3}$ & 33.92 & 5.57 & 4.99 & 1.54 & 1.68 \\
\hline $\mathbf{4}$ & 22.93 & 10.28 & 1.19 & 0.91 & 1.93 \\
\hline $\mathbf{5}$ & 39.46 & 9.22 & 4.79 & 0.81 & 2.27 \\
\hline $\mathbf{6}$ & 45.83 & 4.13 & 1.6 & 2.57 & 1.23 \\
\hline $\mathbf{7}$ & 39.92 & 2.04 & 1.6 & 2.54 & 0.81 \\
\hline $\mathbf{8}$ & 16.68 & 5.08 & 1.65 & 2.74 & 0.82 \\
\hline $\mathbf{9}$ & 35.59 & 2.57 & 1.93 & 1.08 & 1.4 \\
\hline $\mathbf{1 0}$ & 46.5 & 4.89 & 4.02 & 1.65 & 0.71 \\
\hline Mean & 34.692 & 5.286 & 2.723 & 1.626 & 1.434 \\
\hline Std Dev & 8.936 & 1.32 & 0.42 & 0.37 & 0.21 \\
\hline
\end{tabular}


Table (2): Mean values of area \% of estrogen receptors immunoreactivity in prostate of untreated group.

\begin{tabular}{|c|c|c|c|c|c|}
\hline Age & 2 days & 1 week & 2 weeks & 4 week & 6 week \\
\hline $\begin{array}{c}\text { Area } \% \pm \\
\text { SD }\end{array}$ & $34.7^{* *} \pm 8.9$ & $5.3^{*} \pm 1.3$ & $2.7 \pm 0.4$ & $1.6 \pm 0.4$ & $1.4 \pm 0.2$ \\
\hline
\end{tabular}

$\mathrm{P}<0.001 \quad$ Very highly significant **

$\mathrm{P}<0.05 \quad$ Significant *

Table (3): Mean area \% of the positive ER Immunoreactivity in rat prostate of the treated group

\begin{tabular}{|c|c|c|c|}
\hline $\begin{array}{c}\text { No of speci- } \\
\text { men }\end{array}$ & Subgroup 1 & Subgroup 2 & Subgroup 3 \\
\hline $\mathbf{1}$ & 7.68 & 1 & 2.17 \\
\hline $\mathbf{2}$ & 8.85 & 2.51 & 0.77 \\
\hline $\mathbf{3}$ & 11.86 & 0.96 & 1.05 \\
\hline $\mathbf{4}$ & 7.12 & 2.98 & 1.36 \\
\hline $\mathbf{5}$ & 9.56 & 1.83 & 0.79 \\
\hline $\mathbf{6}$ & 10.5 & 2.73 & 0.18 \\
\hline $\mathbf{7}$ & 6.31 & 1.42 & 1.51 \\
\hline $\mathbf{8}$ & 7.86 & 2.23 & 0.24 \\
\hline $\mathbf{9}$ & 15.82 & 1.64 & 0.44 \\
\hline $\mathbf{1 0}$ & 4.51 & 6.3 & 0.65 \\
\hline Mean & 9.005 & 2.361 & 0.915 \\
\hline Std Dev & 2.06 & 0.79 & 0.24 \\
\hline
\end{tabular}

Table (4): Mean values of area \% of ER immunoreactivity in control adult and treated subgroups

\begin{tabular}{|c|c|c|c|c|}
\hline Group & Adult control & $\begin{array}{c}\text { Treated } \\
\text { subgroup 1 }\end{array}$ & $\begin{array}{c}\text { Treated sub- } \\
\text { group 2 }\end{array}$ & $\begin{array}{c}\text { Treated sub- } \\
\text { group 3 }\end{array}$ \\
\hline $\begin{array}{c}\text { Area\% } \\
\pm \mathbf{S D}\end{array}$ & $1.4 \pm 0.2$ & $9^{* * \pm 2.1}$ & $2.4^{*} \pm 0.8$ & $0.92 \pm 0.2$ \\
\hline
\end{tabular}

$P<0.001$ Very highly significant **

$P<0.05$ Significant * 
revealed positive ER reaction in the epithelial cells of acini, as well as, stromal cells both in cytoplasm and nucleus. (Fig.17). By the image analyzer, the mean area percent of the positive ER immunorectivity was 2.361 (table 3) compared to 1.4 in the control group which was statistically significant (table 4).

Subgroup 3: on examination of immunostained sections of this subgroup, positive ER reaction was demonstrated in the cytoplasm and nuclei of the acinar cells, as well as, some stromal cells (fig. 18) .By the image analyzer, the mean area percent of the positive ER immunorectivity was 0.915 (table 3 ) compared to 1.4 in the control group which was non significant (table 4).

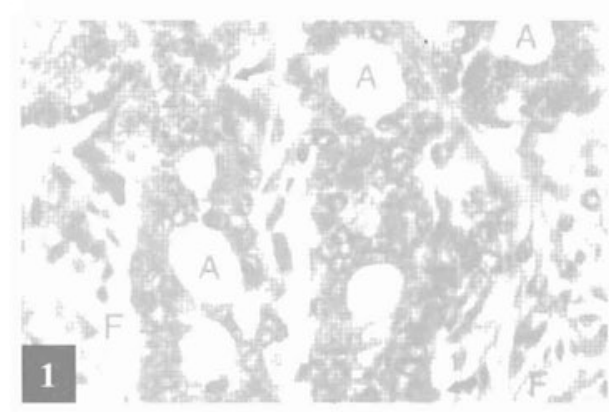

Fig. (1): A photomicrograph of a section of rat prostate from the untreated subgroup (1) showing epithelial cords (arrows), some of these cords form small acini (A), most of acini are lined by more than one layer of cubical cells. The fibromuscular stroma $(F)$ is abundant.

(H \& $E ; \times 400)$

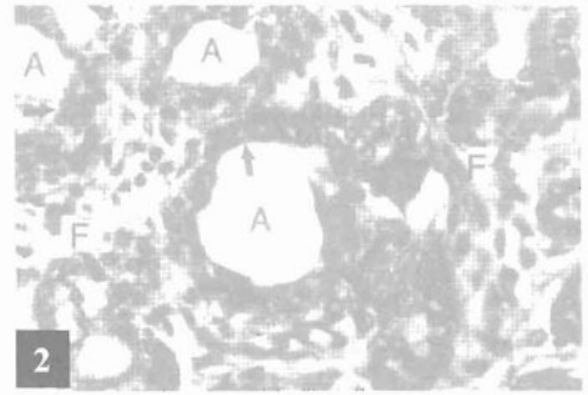

Fig. (2): A photomicrograph of a section of rat prostate from the untreated subgroup (2). Prostatic acini (A) became more obvious with presence of few epithelial cords. Most of the prostatic acini are lined by more than one layer of cubical cells (arrows). The fibro muscular stroma $(F)$ is abundant.

$(H \& E ; \times 400)$ 


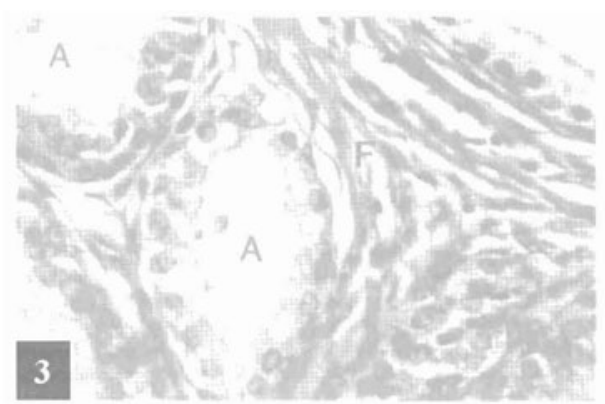

Fig. (3): A photomicrograph of a section of rat prostate from the untreated subgroup (3) showing more developed prostatic acini (A). Most of these acini are lined by one layer of cubical cells with wide central lumina. The fibro muscular stroma $(F)$ is less abundant.

(H \& E; $\times$ 400)

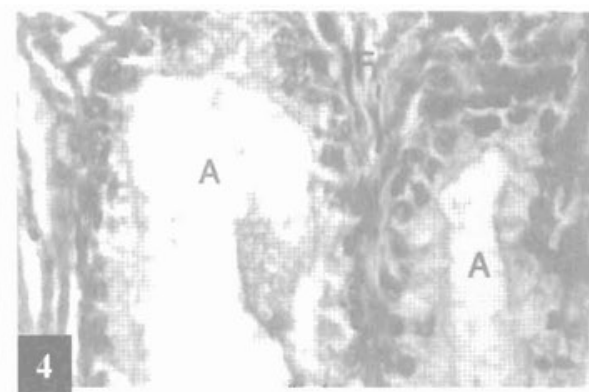

Fig. (4): A photomicrograph of a section of rat prostate from the untreated subgroup (4) showing well developed prostatic acini (A), which are lined by one layer of cuboidal or low columnar cells with wide central lumina. The fibro muscular stroma $(F)$ is greatly reduced.

(H \& E; x 400)

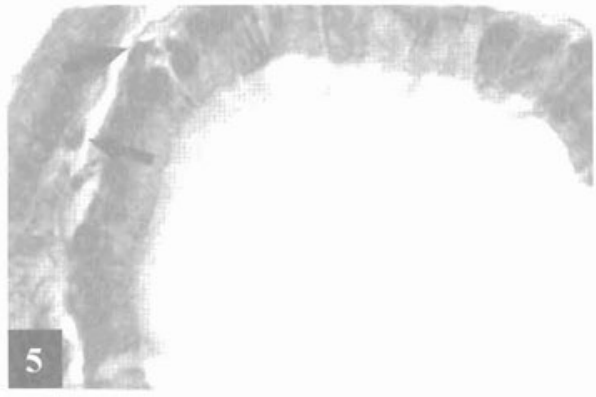

Fig. (5): A photomicrograph of a section of rat prostate from the untreated subgroup (5) showing prostatic acinus (A) lined by columnar epithelium with large central lumen (fully developed acinus). Basal cells (arrows) with flattened nuclei can be seen between the columnar cells and basal membrane.

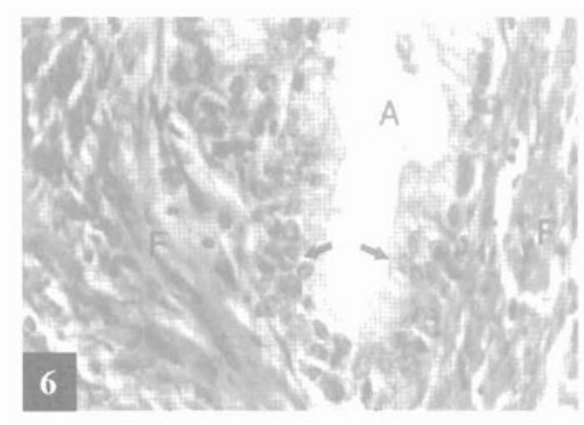

Fig. (6): A photomicrograph of a section of rat prostate from the treated subgroup (1) showing a prostatic acinus (A) with small central lumen lined partially by more than one layer (hyperplasia) of epithelial cells (arrows). The fibro muscular stroma $(F)$ is abundant.

(H \& E; x 400)

$(H \& E ; x 400)$ 


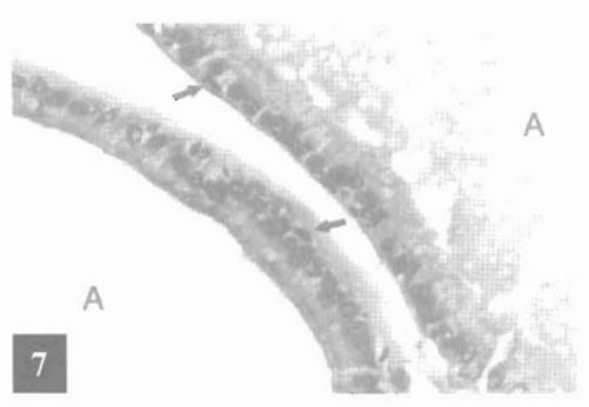

Fig.(7): A photomicrograph of a section of rat prostate from the treated subgroup (2) showing no histological changes from the control group. The acini (A) are lined by columnar cells. Also basal cells (arrows) can be seen.

(H \& E; $x$ 400)

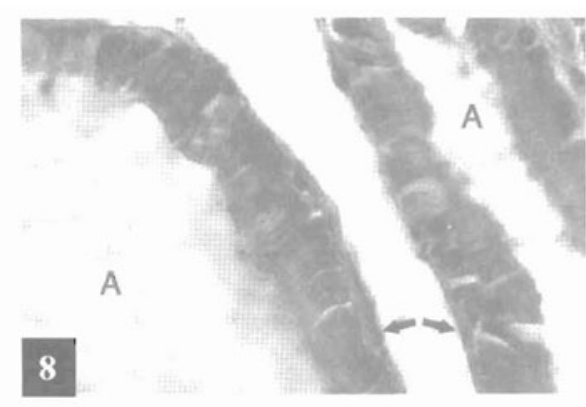

Fig. (8): A photomicrograph of a section of rat prostate from the treated subgroup (3). No histological difference could be observed from the control group. The acini (A) are lined by columnar cells. The basal cells (arrows) can be seen.

(H\& E; x 400)

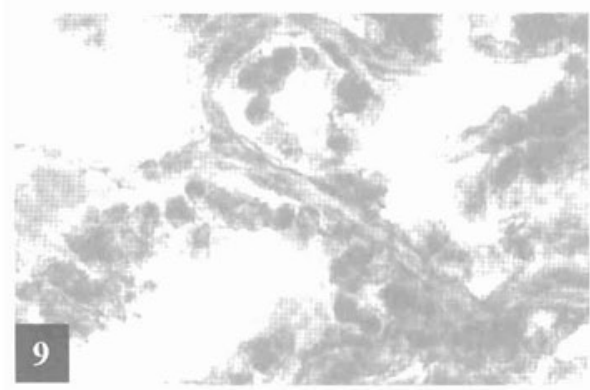

Fig. (9): A photomicrograph of a section of breast carcinoma, showing a strong positive ER reaction (+ve control) in cytoplasm and nuclei of malignant cells.

(Immunostaining; $\times$ 1000)

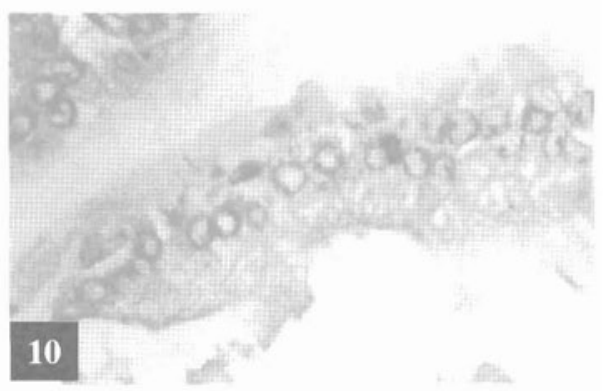

Fig. (10): A photomicrograph of a section of the prostate of negative control, showing that there is no ER immunoreactivity either in the cytoplasm or in the nucleus of acinar cells.

(Immunostaining; $\times 1000)$ 


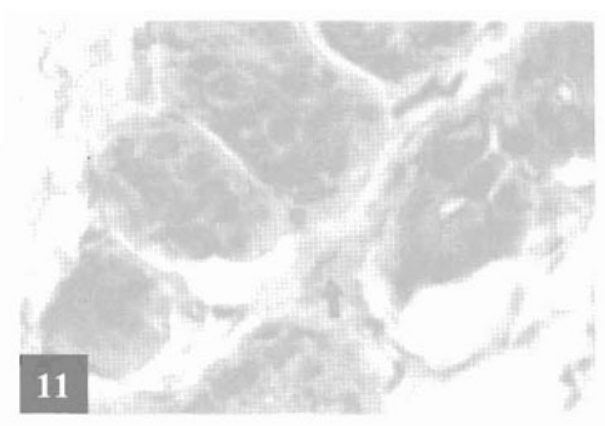

Fig. (11): A photomicrograph of a section of rat prostate from untreated subgroup (1), showing strong positive ER reaction in both cytoplasm and nuclei of acinar epithelial cells. The stromal cells (arrow) show strong positive ER reaction.

(Immunostaining; $\times$ 1000)

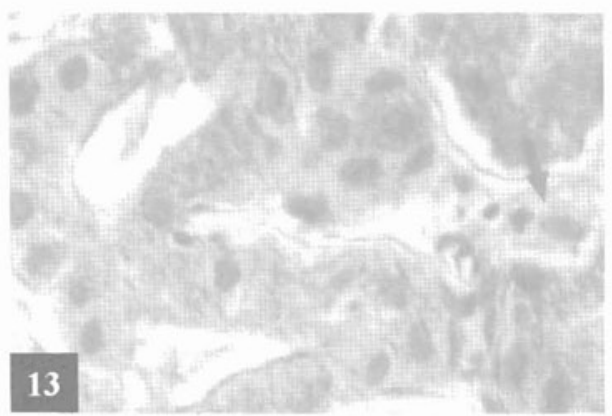

Fig. (13): A photomicrograph of a section of rat prostate from untreated subgroup (3) showing positive ER reaction of both cytoplasm and nuclei of the acinar cells. The stroma cells give weak ER immunoreactivity.

(Immunostaining; $x$ 1000)

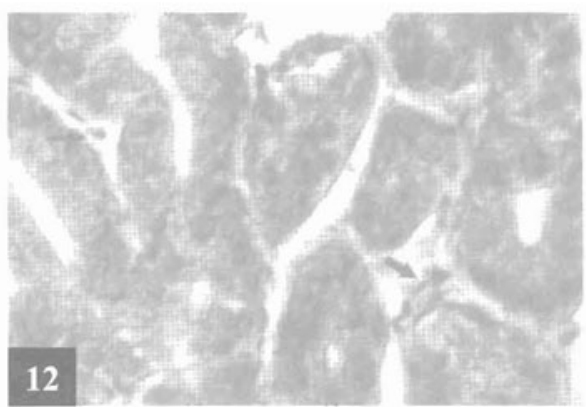

Fig. (12): A photomicrograph of a section of rat prostate from the untreated subgroup (2) showing positive ER reaction in both cytoplasm and nuclei of acinar epithelial cells. The cells of fibromuscuar stroma (arrows) show strong ER immunoreactivity.

(Immunostaining; $x$ 1000)

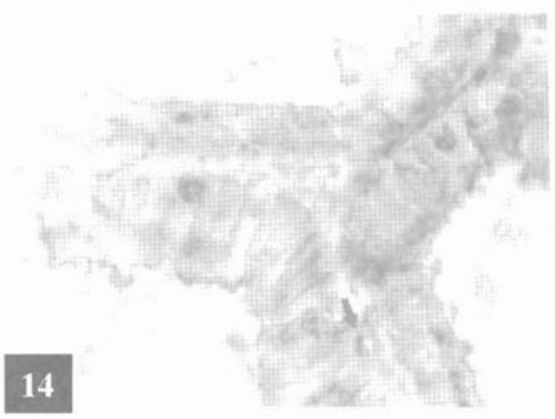

Fig. (14): A photomicrograph of a section of rat prostate from untreated subgroup (4) showing ER immunoreactivity in cytoplasm and some nuclei of most acinar cells. The stroma cells (arrow) show positive ER reaction.

(Immunostaining; $\times$ 1000) 


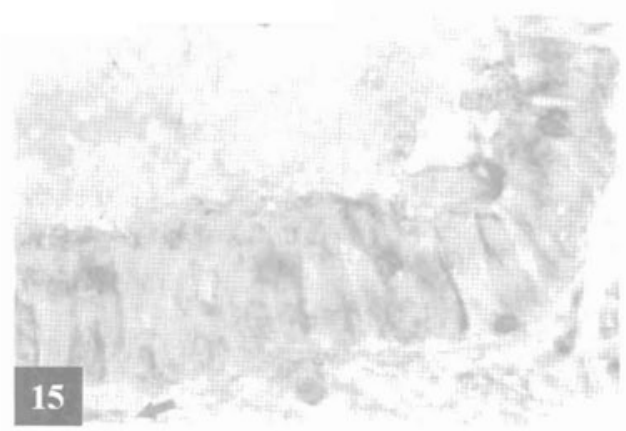

Fig. (15): A photomicrograph of a section of a rat prostate from untreated subgroup (5) showing positive ER reaction in the cytoplasm of most of the acinar cells, while it is positive in few nuclei. Some stromal cells show positive ER reaction.

(Immunostaining; $x$ 1000)

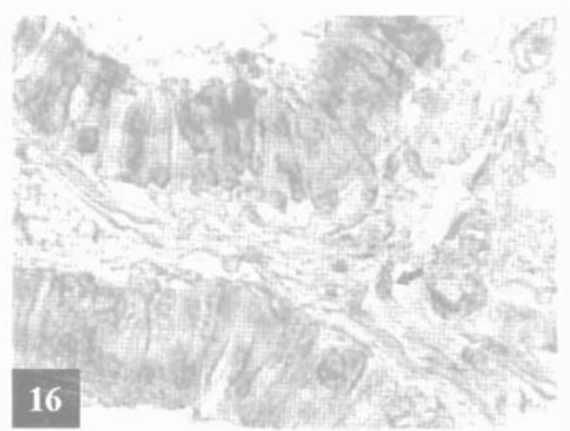

Fig. (16): A photomicrograph of a section of rat prostate from treated subgroup (1) showing strong positive ER reaction in the cytoplasm and nuclei of the acinar cells. The stromal cells show strong positive ER reaction.

(Immunostaining; $x$ 1000)

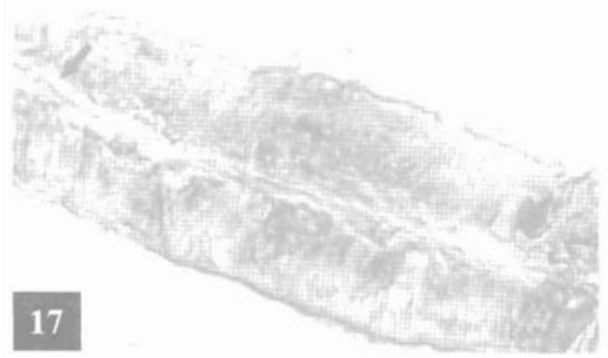

Fig. (17): A photomicrograph of a section of rat prostate from treated subgroup (2) showing ER immnoreactivity in both cytoplasm and nuclei of acinar cells as well as stoma cells (arrow).

(Immunostaining; x 1000)

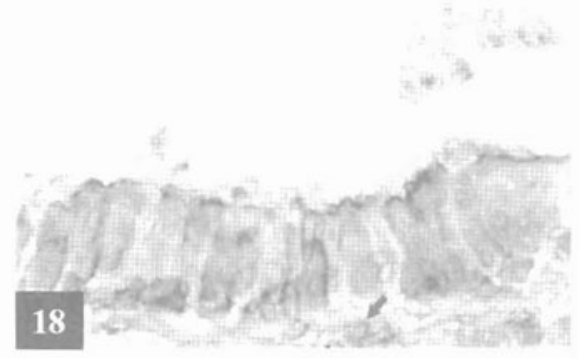

Fig. (18): A photomicrograph of a section of rat prostate from treated subgroup (3) showing ER immunoreactivity in cytoplasm and nuclei of acinar cells as well as some stromal cells (arrow). Immunostaining; $x$ 1000) 


\section{DISCUSSION}

\section{Histological Results}

Regarding the untreated group, histological results of subgroup (1) of the present study are in agreement with the results obtained by McNeal (1978) and Higgins et al. (1989). They reported that at birth the rat ventral prostate consists of four main epithelial cords derived from the epithelium of the urogenital sinus and process of canalization could be seen by the age of two days postnatal. Moreover, the results of subgroup (2) are in agreement with those obtained by Soeffing and Timms (1995), and Hayward et al. (1996). They found that the first clear canalization in the ventral prostate was seen at the $5^{\text {th }}$ day after birth in regions adjacent to the urethra. By the $6^{\text {th }}$ day, canalization was clearly progressing distally. Also, the histological findings of subgroup (3) confirmed the data obtained by Hayashi et al. (1991) who observed that the differentiation activity of the rat prostate occurred between the $12^{\text {th }}$ and $15^{\text {th }}$ post natal day.

Furthermore, by the age of four weeks observations are in coincidence with the results obtained by Hayward et al. (1996). They reported that by the age of four weeks the prostatic gland reach the adult structure under the effect of testicular testosterone which led to complete canalization of the epithelial cords in a proximal to distal manner. This occurred. concurrently with the differentiation of lining epithelium. In addition, histological results demonstrated in subgroup (5) are the same as those obtained by Hayashi et al. (1991) who reported that the rat prostate by the $6^{\text {th }}$ week were fully developed consisting of large acini with minimal amount of fibro- muscular stroma in-between. They suggested that the adult rat prostate has a pseudostratified columnar epithelium which consists of functionally distinct epithelial cell types, a basal flattened cells between the columnar cells. On the other hand, McNeal (1988) suggested that the secretory cells throughout the prostate were separated from the basement membrane by a layer of basal cells (stratified epithelium). These basal cells were probably the proliferative component of the prostate epithelium. They could divide to give mature columnar secretory cells.

Concerning the treated group, the results of estrogen treated subgroup are in agreement with those achieved by Santi et al. (1990) as well as Prins and Birch (1997). They documented that exogenous estrogens given in the neonatal period caused permanent disturbances in the prostate, including reduced size of acini and hyperplasia of the lining epithelium and fibromuscular stroma, with progression of age. Moreover, Tsurusaki et al. (2003) found that neonatal estrogenization led to benign prostatic hyperplasia later on. Also, Royuela et al. (2001) found that aging in man was associated with a gradual decline of testosterone and relative increase in estrogen which led to epithelial and fibromuscular hyperplasia and, hence, the development of benign prostatic hyperplasia. 
However, in the present study there are no histological differences observed in the prostate of tamoxifen treated subgroup compared to the control group. This is in agreement with the results obtained by Rees (1992).

Also, the histological picture of the prostate of testosterone treated rats showed no obvious histological changes compared to the control group. These findings coincide with those achieved by Donjacour and Cunha (1993) and Irwin et al. (2001). They stated that testosterone, secreted by testis, provided a strong stimulus for normal prostatic tissue growth and development. On the other hand, Cunha et al. (1994) reported that the increase in serum testosterone level might induce prostatic hyperplasia or cancer. However, Higgins and Gehring (1978) postulated that the increase of serum testosterone could lead to increase in the binding capacity of testosterone to globulin and albumin. So, this dynamic equilibrium could maintain the free serum testosterone, which is the functioning portion, within the normal levels. From the previous data, it could be concluded that exogenous testosterone could not affect the normal structure of the prostate. Moreover, Irwin et al. (2001) stated that exogenous administration of testosterone might inhibit the release of luteinizing hormone of pituitary (feed-back mechanism) with subsequent decrease in endogenous secretion of testosterone from the testis. Thus, the serum testosterone might remain in the normal levels.

\section{Immunohistochmical Results}

Regarding the untreated group, the results obtained for subgroup (1) are in agreement with the findings of kuiper et al. (1996). On the other hand, Jensen and Desomber (1973) reported that estrogen receptors might reside primarily in the cell nuclei and the staining in the cytosol fraction would represent receptors that were loosely attached with the nucleus. However, Fixemer et al. (2003) proposed that estrogen combined to estrogen receptors in the cytoplasm then the estrogen- receptor complex was translocated to the nucleus. Estrogen-receptor nuclear interaction could lead to an increase in synthesis of new protein receptor in the cytoplasm of the cell.

In the present study, the results of the prostate of subgroup (2) coincide with those obtained by Corbier et al. (1992) who suggested that maternal estrogen exposure during fetal life led to high levels of circulating estrogens which dropped gradually during the $1^{\text {st }}$ week of neonatal period in the rat and this might be the result of decrease ER expression at the end of the $1^{\text {st }}$ week of life.

The findings observed in subgroup (3) are in agreement with those achieved by Adams et al. (2002). They explained that weak ER immunorectivity in the fibromusclar stroma was due to loss of ER in smooth mus- 
cles, whereas fibroblasts retained estrogen labeling till the $10^{\text {th }}$ day postnatal. The results of the present study of subgroup (4) are in concomitant with the findings obtained by Prins et al. (1996). On the other hand, using insitu hybridization studies, Kuiper et al. (1996) revealed that by the age of four weeks the incidence of ER +ve epithelial cells declined and ER immunoreactivity was lost entirely within the stromal cells of the prostate. This minimal difference in results of the present work and those of Kuiper et al. (1996) could be attributed to the difference in the methods used .Immunohistochemical results of subgroup (5) of the present work are in concordance with those obtained by Irwin et al. (2001) despite of the different methods used for estrogen receptor detection. Corbier et al. (1992) suggested that estrogen possibly played a physiological role in the prostate during the developmental period. This role decreased once development was complete. On the other hand, Prins et al. (1996) suggested that the transpubertal decrease in cytosolic ER levels might be due to occupancy of the receptors by endogenous testosterone.

Regarding the treated group, the results of estrogen treated subgroup are in agreement with those obtained by Sato et al. (1994) who suggested that early estrogenization might induce ER expression in the differentiated cells of the prostate. This regulation of ER expression in the differentiated cells of the prostate persisted through the period of morphogenesis and even after puberty. Thus, early estrogen exposure might be a potential predisposing factor for prostatic disease later on in life. Moreover, Timme et al. (1994) proposed that estrogen administration affected smooth muscle cells, and this would enhance these cells to produce stimulating factors. These factors could stimulate ER induction within the epithelial cells and this paracrine action of smooth muscles persisted, altering the differentiation of prostatic epithelial cells through life.

The increase of estrogen receptors in tamoxifen treated rats of the present work is in accordance with Eijun et al. (2003), who suggested that tamoxifen decreased the estrogen binding to estrogen receptors resulting in the increase of free receptor that bind to the monoclonal antibody. Also, the decrease of estrogen receptors in testosterone treated rats in the present study is in agreement with Kuiper et al. (1996) who suggested that testosterone might block estrogen-induced ER synthesis. On the other hand, Nitta et al.(1994) reported the presence of aromatase in stromal and muscle cells of the developing prostate. Through this enzyme, estrogen could be produced in the prostate from circulating testosterone. However, this proposal was contradicted by Irwin et al. (2001) who suggested that testosterone might act directly on ER in the prostate by occupying these receptors. 


\section{SUMMARY}

The aim of the present work was to illustrate the histological picture of the developing rate prostate and to localize estrogen receptor (ER) distribution in attempt to understand the role of estrogen in the development of this important male accessory gland. It was also aimed to study the effect of estrogen, tamoxifen and testosterone given neonatally, on the histological picture and ER pattern of the adult prostate.

This study was carried out on eighty male albino rats; they were divided into two main groups, treated and untreated groups. The untreated group, consisted of fifty rats which were subdivided into five equal subgroups at ages of two days, $1,2,4$ and 6 weeks, the last subgroup was taken as a control group for treated subgroups. The treated group, included 30 rats at the age of two days which were subdivided into three equal subgroups $1,2 \& 3$ received estrogen, tamoxifen and testosterone respectively. The hormones and the drug were given orally for five successive days starting from the second day. The rats of the untreated subgroups were sacrificed at the age of 2 days, 1 week, 2 weeks, 4 weeks and 6 weeks respectively. The rats of the treated subgroups were sacrificed at the age of six weeks. The prostates were dissected and specimens were obtained from the ventral lobe of each. Specimens were subjected to haematoxylin and eosin stain and immunohistochmical technique for estrogen receptors.

The present study revealed that the prostate of two days old rat consisted of epithelial cords with starting canalization. By the age of one week, small acini appeared which increased gradually till it reaches full maturation by the sixth week. The results also showed that the estrogen receptors decreased gradually with the increase of age and the decrease was markedly observed in the adult prostate. Administration of estrogen resulted in increased estrogen receptors markedly in adults while; tamoxifen administration increased moderately the estrogen receptor level in adults. Administration of testosterone resulted in the diminished estrogen receptors. It is concluded that the prostate in spite of being androgen dependant gland, depends greatly on estrogen in the development in the prepubertal period and the estrogen treatment early in life could lead to structural disturbances in the gland, which might lead to development of prostatic disease later on. 


\section{REFERENCES}

1. Adams, J.; Leav, I.; Lau, K.; HO, S. and Pflueger, S. (2002): Expression of estrogen receptor beta in the fetal, neonatal, and per pubertal human prostate, Prostate, 52: 69-81.

2. Bryan, J.; William, H. and William, A. (1983): Estrogen receptor in human benign prostatic hyperplasia. J. Urol., 130: 183-187.

3. Chaisiri, N.; Volataire Y.; Bronwen, E. and Pierrepoint, C. (1978): Demonstration of a cytoplasmic receptor protein for oestrogen in the canine prostate gland. Endocrinol., $78: 131-138$.

4. Corbier, P.; Edwards, D. and Roffi, J. (1992): The neonatal testosterone surge: a comparative study. Arch Int. physiol. Biochem. Biophys .,100:127-131.

5. Cote, R. and Taylor, C. (1996): Immunhistochemistry and related marking techniques: Anderson pathology. $10^{\text {th }}$ ed. Damjanov I. and Lindr J. (eds) $10^{\text {th }}$ ed., Mosby-year book, Inc., St Louis, Missouri, 136.

6. Creasy, D. and Foster, P. (1991): Male Reproductive System: In "Hand Book of Toxicologic Pathology". Academic Press Inc., 829.

7. Cunha, G.; Forst, B. and Lopes, E. (1994): Expression of prostatic secretion proteins in rat prostate.Proc. Am. Assoc. Cancer Res., 35:1683-1691.

8. Donjacour, A. and Cunha,G. (1993): Assessment of prostatic protein secretion in tissue recombinants made of urogenital sinus mesenchyme and urothelium from normal or androgen-insensitive mice. Endorinol, $131: 2342-2350$.

9. Eijun, N.; Yuji, N.; Satoshi, I.; Hisahiko, H.; Masami, M.; Shunichi, Y. and Takehiko, K. (2003): Ontogenic Changes in the expression of Estrogen Receptor in rat tissue detected by immunohistochemistry. Endocrinol., $141: 615-620$.

10. Fixmer, T.; Remberger, K. and Bonkhoff, H. (2003): Differential expression of the estrogen receptor in human prostate tissue, premalignant changes, and in primary, metastatic, and recurrent prostatic adenocarcinoma. Prostate, 54: 79-87.

11. Hayashi, N.; Sugimura, Y.; Kawamura, J.; Donjacour, A. and Cunha, G. (1991): Morphological and functional heterogenicity in the rat prostatic gland. Biol. Reprod., 45: 308-321. 
12. Hayward, S.; Brody, J. and Cunha, G. (1996): An edgewise look at basal cells: three-dimensional views of the rat porstate, mammary gland and salivary gland. Endocrinol., $136: 913-920$.

13. Higgins, S. and Gehring, U. (1978): Molecular mechanisms of steroid hormone action. Adv. Cancer. Res., 28.313-319.

14. Higgins, S.; Young, P. and Cunha, G. (1989): Induction of functional cytodifferentiation in the epithelium of tissue recombinants. Instructive induction of Wolffian duct epithelium by neonatal seminal vesicle mesenchyme. Development, 106:235-250.

15. Irwin, L.; Kin, M.; Jason, Y. and John, E. (2001): Comparative study of the estrogen and the androgens receptors in normal human prostate glands, Dysplasia and in primary and metastatic carcinoma. Am. J. Pathol., $159: 79-92$.

16. Jensen, E. and Desomber, E. (1973): Intracellular localization of estrogen receptors. Science, 182: 126-134.

17. Juniewicz, P.; Lemp, B.; Barvolt, T.; Labrie, T.; Batzold, F. and Reel, J. (1989): Dose-dependant hormonal induction of benign prostatic hyperplasia (BPH) in castrated dogs. Prostate, 14: 341-352.

18. Kuiper, G.; Enmak, E.; Pelto-Huikko, M.; Nilsson, S. and Gustaffson, J. (1996): Cloning of a novel estrogen receptor expressed in rat prostate and ovary. Proc. Natl. Acad Sci. (USA), 93: 5925-5930.

19. McLachlan, J. (1981): Rodent models of perinatal exposure to diethylstilbestrol and their relation to human disease in the male; Developmental Effects of Diethylstilbestrol (DES) in pregnancy. Herbst, A., Bern, H. (eds), Thieme-Stratton, New York, 148.

20. McNeal, J. (1978): Origin and evolution of benign prostatic enlargement. Invest. Urol. , 15: $340-352$.

21. McNeal, J. (1988): Normal histology of the prostate. Am. J. surg. Pathol., $12: 609-618$.

22. Micheal, J.; Naslund, M. and Donald, S. (1986): The differential effect of neonatal androgen, estrogen and progesterone on adult rat prostate growth. Urol., 136:1136-1140.

23. Moverare, S.; Venken,K. ;Eriksson, A.; Anderson, N. ; Skrtic, S. ; Wergedal, J. ;Mohan, S.; Salmon, P.; Bouillon, R.;Gustafsson, J.; Vanderschueren, D. and Ohlsson C.(2003): Differential effects on bone of estrogen receptor alpha and androgen receptor activation in 
orchidectomized adult male mice .Proc. Nat. Acad. Sci. (USA), $100: 13573-13578$.

24. Niu, Y.; Ma, T.; Zhang, J.; Xu, Y.; Han, R. and Sun, G. (2003): Androgen and prostatic stroma. Asian J. Androl., 5 (1): 19-26.

25. Nitta, H.; Bunick, D.; Osawa, Y. and Coke, P. (1994): Localization of aromatase in the rat ventral prostate. $27^{\text {th }}$ Annual Meeting of the society for the study of reproduction, Ann Arbor Ml, p. 140.

26. Paget, G. and Barnes, J. (1964): Interspecies dosage conversion; Pharmacometrics . 1st ed. , Laurence, D. and Bachard, A. (eds.),(USA), 135.

27. Prins, G. and Birch, L. (1997): Neonatal Estrogen Exposure UpRegulates Estrogen Receptor Expression in the Developing and Adult Rat prostate lobes. Endocrinol., $137: 1801-1809$.

28. Prins, G.; Birch, L; Ye, S. and Ray, V. (1996): Estrogen exposure leads to prostate lobe specific dysplasia and adenomas in the aging rat. $21^{\text {st }}$ annual meeting of the American society of Andrology, Minneapolis MN, p 52.

29. Pylkanen, L.; Santti, R. and McLachlan, J. (1991): Regional differences in the prostate of the neonatally estrogenized mouse. Prostate, 18:117-129.

30. Rees, D.(1992): Restricted entry to the tamoxifen trial. Br. Med J., 307: 747-749.

31. Royuela, M.; Bethencourt, F.; Sanchez-Chapdo M.; Fraile, B.; Aneras, M. and Paniague, R. (2001): Estrogen receptors alpha and beta in the normal, hyperplastic and carcinomatous human prostate.J.Endocrinol., 168(3):447-454.

32. Santi, R.; Pylkanen, L.; Newbold, R. and McLachlan, J. (1990): Developmental estrogenization and prostatic neoplasia. Int. J. Androl., 13: $77-80$.

33. Sato, T.; Chiba, A.; Hayashi, S.; Okamura, H.; Oht, Y.; Takasugi, N. and Iguchi, T. (1994): Induction of estrogen receptor and cell division in genital tract of male mice by neonatal exposure to diethylstilbestrol. Reprod. Toxicol., 8 : 145-153.

34. Soeffing, W.and Timms, B. (1995): Localization of androgen receptor cell-specific cytokeratins in basal cells of rat ventral prostate. J. Androl., 16: 197-208. 
35. Timme, T.; Truing, L.; Merz, V.; Krebs, T.; Kadmon, D.; Flanders, K.; Park, S. and Thompson, T. (1994): Mesenchymal-epithelial interactions and transforming growth factor expression during mouse prostate morphogenesis .Endocrinol., 134:1039-1045.

36. Tsurusaki, T.; Aoki, D.; Kanetake H.; Muramatsu, M.; Hishikawa, Y. and Koji, T. (2003): Zone dependant expression of estrogen receptors in benign prostatic hyperplasia. J. Clin. Endocrinol. Metab., 88 (3) : 1333-1340.

37. William, Y.; Michel, J.; Birch,L. and Prins,G. (1999): Neonatel esterogen stimulates proliferation of periductal fibroblasts and alters the extra cellular matrix composition in the rat prostate. Endocrinol., 139 : 405-415. 


\section{الملفص العربى}

تأثيراعطاء بعض العقاقير في فترة حليثي الولادة علي مستقبلات

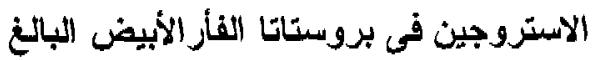

\section{دراسة هستولوجيه و هستوكيميائية مناعية}

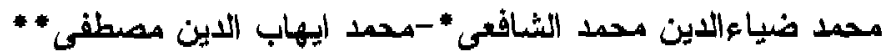

"قتسم الهستولوجى-كلية الطب-جامعة القاهرة.

"* *قم الثثريح-كلية الطب -جامعة القاهرة

يهاف هذا البحث إلى توضيح التزكيب البنائي لأنسجة بروستاتا الفار الأبيض في طور

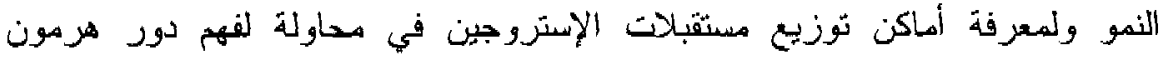

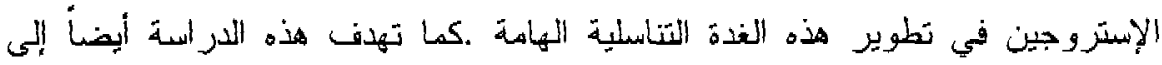

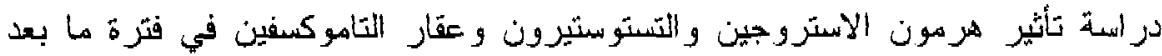

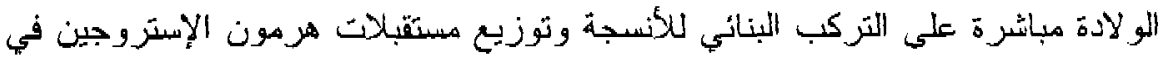

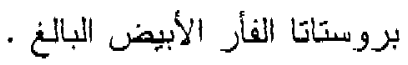
وقد أجريت هذه الدراسة طلي عينات تم الحصول عليها من الفص البطني لبروسئاتا

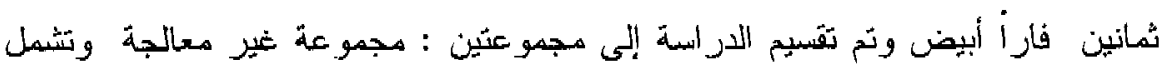

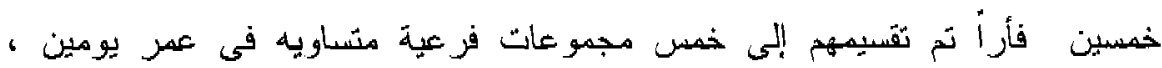

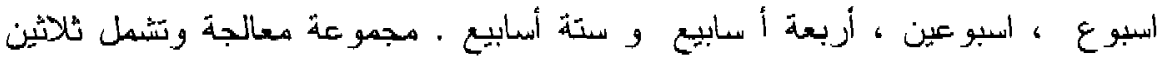

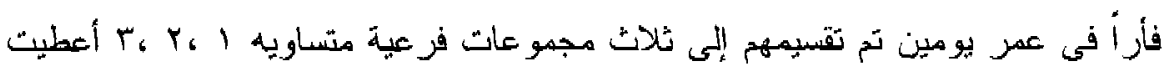

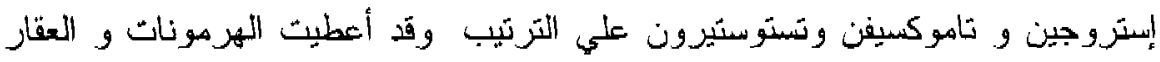

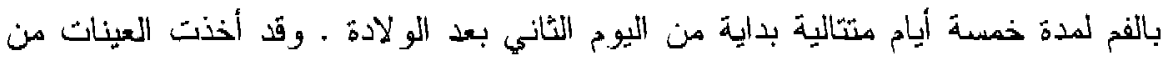

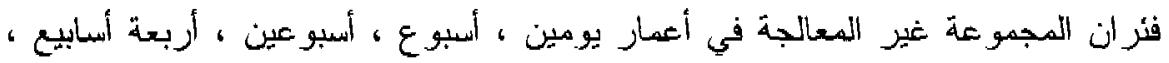

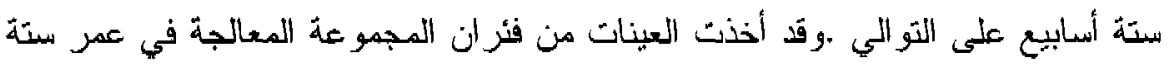

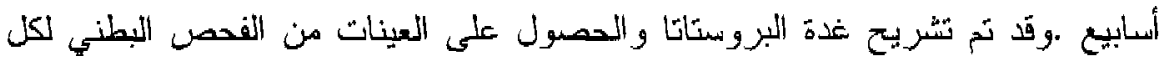

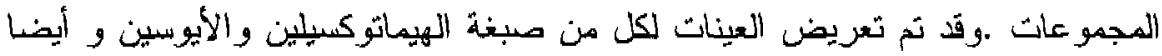
لتقنية الهيتوكيميائية المناعية لمستقبلات الأستروجين. 
وقد أظهرت هذه الدر اسة أن بروستانا الفأر في عمر يومين تنكون من أجبال من

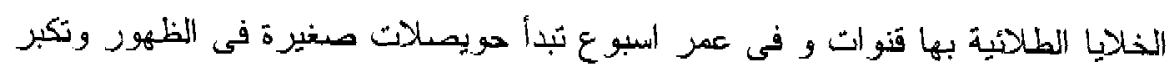

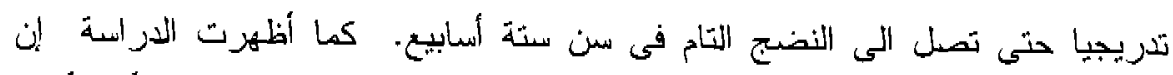

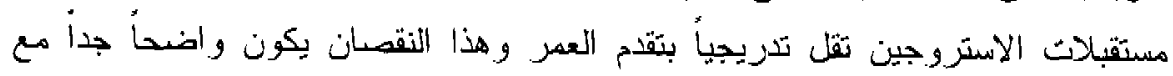

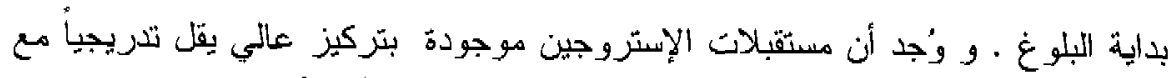

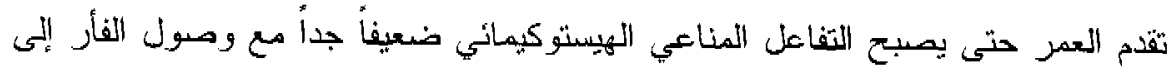

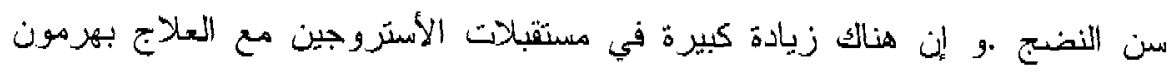

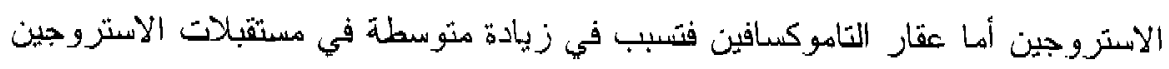

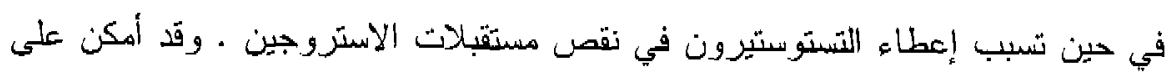

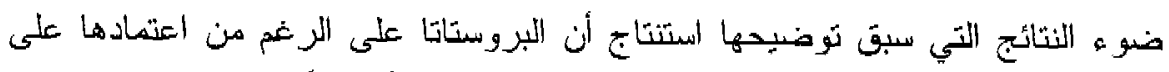

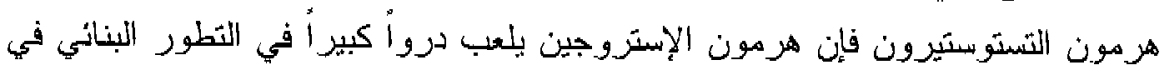

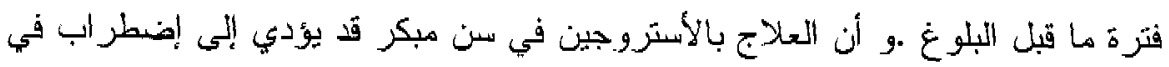

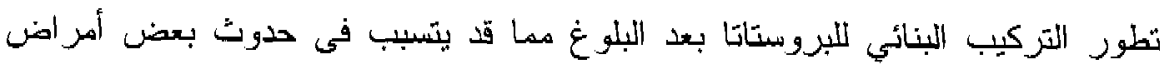

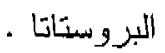

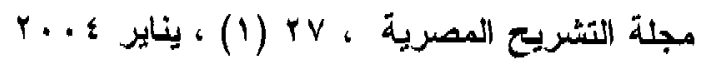

